\title{
POLLEN ATAU SERBUK SARI : ASPEK MORFOLOGI, SISTEMATIKA DAN APLIKASINYA PADA TUMBUHAN KELUARGA MENTOL
}

\author{
Sudarmono dan Sahromi \\ Pusat Konservasi Tumbuhan - Kebun Raya Bogor, LIPI \\ Jl. Ir. H. Juanda No. 13 Bogor 16003 \\ Phone/Fax. 0251-8322187 \\ e-mail : s_darmono@yahoo.com
}

\author{
ABSTRACT \\ Pollen Powder or Sari : Aspects of Morphology, Systematics \\ and Application on Menthol Family Plant
}

\begin{abstract}
Pollen is the important component of plant to develop through reproductive. Pollen is the male organ of plants that plays an important role in the process of the evolution of plants. Menthol family plants (the Family Lamiaceae) is one of biggest families after Asteraceae. The process of the cross breeding often dominates the process of the evolution to the ment al Family. The research on the menthol Family's pollen aimed to know the affinity and the process of his pollination. The form of pollen of the Family Lamiaceae, was round and hexacolpate, the form was the same as the species member with their relatives. In the process of pollination often helped by the bee where pollen that clung to the abdomen part and the chest of the bee and moved to the other flower where the cross-pollination happen. The process of the cross-pollination happened also because of the same of maturity time between pollen of male and the stigma surface of female. The seed was still being the dominant factor in the reproductive in the Family Lamiaceae.
\end{abstract}

Key words : Pollen, Pollination, Lamiaceae, the Mint family, the bee, the seed

\begin{abstract}
ABSTRAK
Serbuk sari atau dikenal dengan pollen merupakan komponen penting tanaman untuk berkembang melalui reproduktif. Serbuk sari merupakan organ jantan pada tumbuhan yang berperan penting dalam proses evolusi tumbuhan. Tumbuhan Keluarga Mentol (Famili Lamiaceae) merupakan salah satu Famili yang terbesar setelah Asteraceae. Proses perkawinan silang banyak mendominasi proses evolusi pada Keluarga Mentol. Penelitian terhadap serbuk sari Keluarga Mentol bertujuan untuk mengetahui kekerabatan dan proses penyerbukannya. Bentuk morfologi serbuk sari pada Famili Lamiaceae, yaitu bulat dan heksakolpat (hexacolpate), bentuk yang sama dengan jenis - jenis anggota Famili Lamiaceae. Pada proses penyerbukan banyak dibantu oleh lebah dimana pollen yang menempel pada bagian perut dan dada lebah penyerbuk dan berpindah pada bunga yang lain sehingga terjadi penyerbukan silang. Proses penyerbukan silang terjadi juga karena adanya waktu pemasakan yang sama antara serbuk sari sebagai organ jantan dan kepala putik sebagai organ betina. Biji masih merupakan faktor yang dominan pada perbanyakan Famili Lamiaceae.
\end{abstract}

Kata kunci : Serbuk sari, Pollen, Lamiaceae, Keluarga Mentol, Lebah, biji.

\section{PENDAHULUAN}

Pollen adalah serbuk kasar yang mengandung benih tanaman microgametophytes, yang menghasilkan gamet jantan (sel sperma). Serbuk sari memiliki mantel keras yang melindungi sel-sel sperma selama proses gerakan mereka antara benang sari ke putik tanaman berbunga atau dari kerucut jantan (cone) untuk betina pada organ reproduksi tanaman konifer. Ketika serbuk sari di putik kompatibel pada tanaman berbunga, maka berkecambah dan menghasilkan tabung polen yang mentransfer sperma ke ovula dari ovarium reseptif. Transfer serbuk sari terhadap struktur reproduksi wanita (putik dalam angiosperma) disebut penyerbukan. Transfer ini bisa dimediasi oleh angin (anemophilous) pada serbuk sari yang sangat ringan. Tanaman berbunga Anemophilous umumnya 
memiliki bunga mencolok. Tanaman entomophilous menghasilkan serbuk sari yang relatif berat, lengket dan kaya protein dan untuk penyebarannya oleh serangga penyerbuk. Banyak serangga dan beberapa tungau yang khusus untuk memakan serbuk sari, dan disebut palynivores.

Butir tepung sari ketika ditempatkan pada stigma, di bawah keadaan yang menguntungkan, akan membentuk suatu tabung polen (pollen tube) yang tumbuh menuju ke ovarium, dan membuat jalan sepanjang plasenta ke mulut ovula. Inti sel tabung akan membentuk sel - sel sperma.

Penelitian ini bertujuan untuk mengetahui secara jelas morfologi serbuk sari atau pollen sebagai organ reproduksi jantan dan proses penyerbukannyan khususnya pada tanaman Keluarga Mentol.

\section{BAHAN DAN METODE}

Sampel serbuk sari atau pollen dari anggota Keluarga Mentol (Famili Mint atau Lamiaceae / Labiatae), yaitu Orthosiphon aristatus dan O. sp yang berasal dari Papua Barat dipasang pada slide mikroskop dan diperiksa menggunakan mikroskop cahaya di Laboratorium kultur jaringan Kebun Raya Bogor dan mikroskop elektron scanning (SEM) di Laboratorium Zoologi, Cibinong Science Centre. Setelah serbuk sari diidentifikasi, kemudian diplot pada diagram serbuk sari, yang kemudian digunakan untuk interpretasi. Metode yang digunakan dalam pembuatan preparat ini adalah acetolisis yang merupakan pelisisan dengan menggunakan asam. Bagian yang dilisis adalah kotoran pada dinding dinding serbuk sari agar bersih sehingga mudah diamati. Pelisisan terjadi pada waktu merendam serbuk sari pada Asam Acetat Glasial (AAG). Fungsi sentrifus (pengocokan) dengan Asam Acetat dan Sulfat adalah untuk mengendapkan serbuk sari, sehingga mudah untuk memisahkannya dari kotoran pada waktu pergantian cairan. Proses ini dapat dilakukan beberapa kali sampai serbuk sari dapat benar - benar bersih dari kotoran. Setelah itu diwarnai dengan safranin dan ditutup dengan gelas penutup yang sebelumnya serbuk sari ditetesi dengan gliserin jeli sebagai perekat dan setiap sudut gelas penutup diberi sedikit potongan kecil parafin. Penutupan dilakukan dengan hati - hati untuk memperkecil kemungkinan timbul gelembung.

Perbandingan morfologi digunakan pada marga lain sesama anggota Famili Lamiaceae, yaitu marga Scutellaria dan marga Leonotus dari referensi Jurnal Internasional. Serbuk sari diperiksa dengan mikroskop elekron pemindai (SEM), dan perwakilan terbaik difoto secara umum dan rinci. Pada setiap sampel, 50 serbuk sari diukur dalam rangka untuk mendapatkan nilai - nilai ukuran maksimum, minimum dan rata - rata. Pengamatan juga dilakukan pada terjadinya tabung pollen atau pollen tube.

Ukuran serbuk sari dibedakan dalam enam kelas, berdasarkan aksis terpanjang (kecuali pada serbuk sari yang ekinat, maka durinya tidak dimasukkan dalam ukuran). Pembagian kelas ukuran tersebut adalah :

$\begin{array}{lll}<10 \mu \mathrm{m} & = & \text { sangat kecil } \\ 10-25 \mu \mathrm{m} & = & \text { kecil } \\ 25-50 \mu \mathrm{m} & = & \text { sedang } \\ 50-100 \mu \mathrm{m} & = & \text { besar } \\ 100-200 \mu \mathrm{m} & = & \text { sangat besar } \\ >200 \mu \mathrm{m} & = & \text { raksasa. }\end{array}$

Terminologi pollen mengikuti Faegri dan Iversen (1989) dan Punt et al. (1994).

\section{HASIL DAN PEMBAHASAN}

\section{Morfologi, anatomi dan kandungan isi pollen}

Serbuk sari atau pollen merupakan komponen seksual jantan pada tumbuh tumbuhan. Serbuk sari mempunyai kandungan protein yang tinggi. Bentuk morfologi serbuk sari biasanya simetris, isopolar, oblate-spheroidal sampai prolatespheroidal atau sub-prolate sampai suboblate (Perveen \& Qaiser, 2003). Dinding serbuk sari Angiospermae terdiri dari dua 
lapisan : eksin (lapisan luar) dan intin (lapisan dalam). Eksin tersusun atas sporopolenin, sedangkan intin tersusun atas selulosa. Lebih lanjut eksin terbagi atas dua lapisan, yaitu seksin dan neksin. Seksin merupakan lapisan yang memiliki ornamentasi, sedangkan neksin tidak.

Struktur dinding serbuk sari, khususnya bagian eksin, merupakan salah satu karakter yang digunakan dalam identifikasi. Struktur halus eksin dapat dibedakan menjadi tiga tipe, yaitu: tektat, semitektat, dan intektat. Serbuk sari umumnya $3-8$ kolpat (colpate), jarang kolporat (colporate). Serbuk sari pada Orthosiphon aristatus dan O. $\mathrm{sp}$. mempunyai ukuran berturut turut $90 \mu \mathrm{m}$ dan $60 \mu \mathrm{m}$, sedangkan pada Scutellaria baicalensis dan Ocimum basilicum berturut turut $20 \mu \mathrm{m}$ dan $60 \mu \mathrm{m}$ (Gambar 1). Pada marga Orthosiphon dan Ocimum basilicum dapat dikategorikan termasuk serbuk sari yang berukuran besar, sedangkan Scutellaria baicalensis termasuk kecil. Akan tetapi pada keempat taksa tersebut mempunyai bentuk yang sama, yaitu heksacolpat dan bentuk ini umum pada famili Lamiaceae (Gençay, et al. 2008).

Ornamentasi dari eksin secara sistematika memberikan informasi sistematika kekerabatan yang jelas.

Berdasarkan data palinologi maka nilai sistematika ciri - ciri morfologi serbuk sari pada famili Lamiaceae dapat untuk mengevaluasi kekerabatan pada anggota famili Lamiaceae. Karena penelitian ini dilakukan pada semua anggota famili Lamiaceae, maka famili ini tergolong euripalineous (famili yang anggota jenisnya memiliki variasi morfologi serbuk sari) (Moon, et al. 2008). Meskipun setiap jenis menunjukkan variasi morfologi, tetapi juga terdapat persamaan - persamaan yang dapat dijadikan dasar untuk pemisahan atau pengelompokan setiap jenis tumbuhan tersebut.
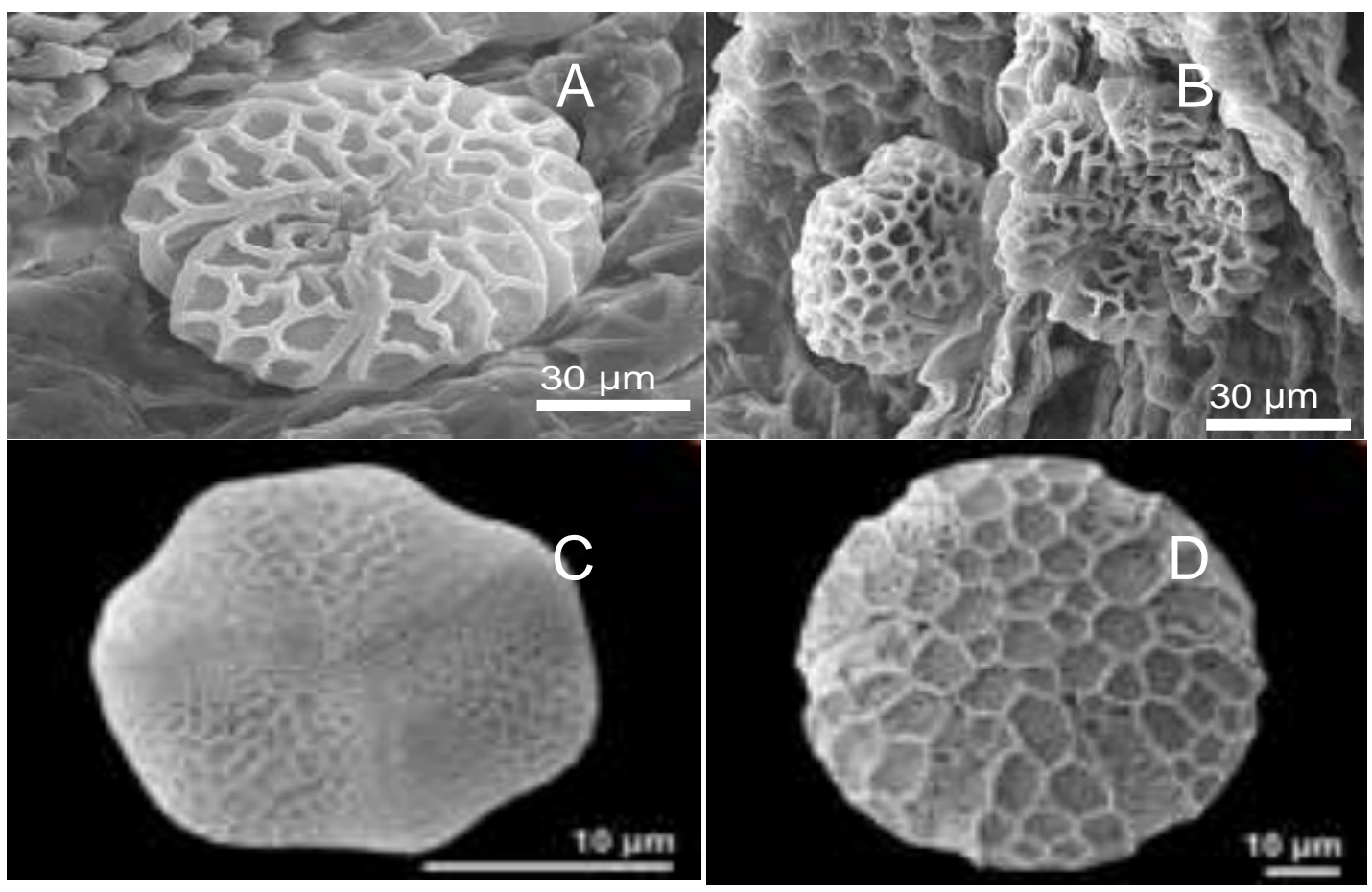

Gambar 1. Serbuk sari Kumis kucing (Orthosiphon aristatus) (A); Orthosiphon sp. dari Papua Barat (B); Scutellaria baicalensis (C) dan Ocimum basilicum (D). 


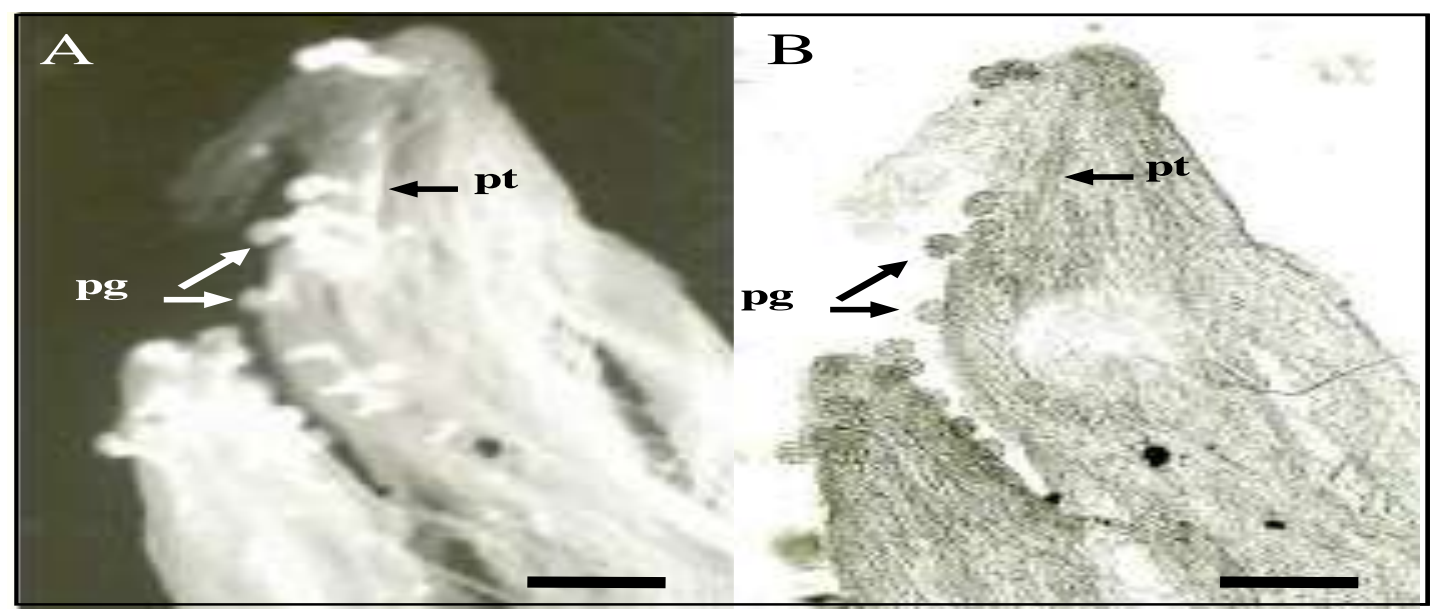

Gambar 2. Serbuk sari Scutellaria slametensis yang berkecambah membentuk tabung pollen pada permukaan kepala putik terlihat pada mikroskop Florescensis (A) dan gambar kontras (B). Pg = butir serbuk sari; pt = tabung pollen. Skala berukuran 100 mikrometer.

Proses persilangan
implementasinya
tanaman

Pada kondisi receptive (matang dan siap dibuahi) maka permukaan kepala putik (stygma) akan mengeluarkan lendir atau bahan perekat sehingga bila ada serbuk sari maka akan menempel (Rodriguez-Rian and Dafni, 2006). Pada masa ini maka serbuk sari akan mudah menempel erat selain itu meskipun terdapat ratusan serbuk sari namun hanya beberapa yang tumbuh tabung pollennya atau pollen tube-nya (Gambar 2). Tabung pollen ini akan memanjang mengikuti saluran organ betina atau tangkai putik dan menuju ovula atau kandung telur. Selanjutnya proses pembuahan terjadi membentuk endosperma yang selanjutnya akan membentuk biji. Biji sebagai alat reproduksi dari suatu tumbuhan yang akan tumbuh sebagai keturunan dari proses penyerbukan jenis jantan atau serbuk sari dengan jenis betina atau kepala putik yang satu jenis. Varietas yang mempunyai morfologi baik warna daun atau warna bunga yang berbeda dapat menghasilkan hibrid atau keturunan yang merupakan kombinasi dari kedua varietas tersebut.

\section{KESIMPULAN}

Serbuk sari atau pollen mengandung bahan protein dan bentuk morfologi serbuk sari mirip satu sama lain pada Keluarga yang sama, yaitu berbentuk heksacolpat seperti pada serbuk sari Famili Lamiaceae atau Keluarga Mentol. Serbuk sari yang kompatibel akan membentuk tabung polen (pollen tube) pada kepala putik atau stygma (organ betina) dan menuju ovula sehingga terbentuk biji. Pada Keluarga Mentol yang berpotensi tanaman hias bisa dilakukan penyerbukan buatan untuk membentuk hibrid hasil persilangan.

\section{DAFTAR PUSTAKA}

Akgül1 Gençay, Osman Ketenoâlu, Nur M. Pinar \& Latif Kurt. 2008. Pollen and seed morphology of the genus Marrubium (Lamiaceae) in Turkey. Ann. Bot. Fennici $45: 1-10$ 
Anonimous, 2011. Palinology data of Scutellaria baicalensis and Ocimum basilicum. http://www.paldat.org/index.php? module $=$ search $\&$ nav $=$ sd $\& I D=20$ 2381\&system $=1$ [accessed 201109-25]

Moon H. K, S. Vinckier, E. Smets, Suzy Huysmans. 2008. Palynological evolutionary trends within the tribe Mentheae with special emphasis on subtribe
Menthinae (Nepetoideae:

Lamiaceae). Plant Syst Evol $275: 93-108$

Rodriguez-R T. and Amots Dafni. 2006. Pollen-Stigma Interference in Two Gynodioecious Species of Lamiaceae with Intermediate Individuals. Annals of Botany. doi:10.1093/aob/mcl168, available online at www.aob.oxfordjournals.or. 